\title{
Analysis of Long Term Variation of the Total Column and Tropospheric Ozone over the Indian Region
}

\author{
C. T. Resmi1, T. Nishanth ${ }^{2 *}$, P. S. Vijoy ${ }^{2}$, M. K. Satheesh Kumar ${ }^{3}$, M. Balachandramohan1 \\ ${ }^{1}$ Department of Physics, Erode Arts and Science College, Tamil Nadu, India \\ ${ }^{2}$ Department of Physics, Sree Krishna College Guruvayur, Kerala, India \\ ${ }^{3}$ Department of Atomic and Molecular Physics, Manipal Academy of Higher Education, Karnataka, India \\ Email: *nisthu.t@gmail.com
}

How to cite this paper: Resmi, C.T., Nishanth, T., Vijoy, P.S., Satheesh Kumar, M.K. and Balachandramohan, M. (2021) Analysis of Long Term Variation of the Total Column and Tropospheric Ozone over the Indian Region. Atmospheric and Climate Sciences, 11, 194-213.

https://doi.org/10.4236/acs.2021.111013

Received: December 19, 2020

Accepted: January 26, 2021

Published: January 29, 2021

Copyright () 2021 by author(s) and Scientific Research Publishing Inc. This work is licensed under the Creative Commons Attribution International License (CC BY 4.0).

http://creativecommons.org/licenses/by/4.0/

\begin{abstract}
Ozone plays a significant part in regulating climate change and the chemical characteristics of the atmosphere. Changes in atmospheric ozone can be studied in more detail using ground-based and satellite-based instruments. Studies on the long-term global changes in total column ozone have begun more than three-decade ago using satellite data. The main objective of this work is to analyze the Total Column Ozone (TCO) variations, and tropospheric ozone variations over different twenty locations in the Indian subcontinent by using Total Ozone Mapping Spectrometer (TOMS) and AURA OMI/MLS data. The long-term analysis of total column ozone is divided into two phases (1979-1994 and 2005-2018), and tropospheric ozone for one phase (2005-2018) in order to detect changes in the ozone trend pattern. The results of linear regression analysis show a declining trend of total column ozone, and an increasing trend of tropospheric ozone over the selected locations. The impact of wind pattern on the variation of ozone has been analyzed by using NCEP reanalysis data, and found that wind patterns played a prominent role in spatial and temporal changes in total and tropospheric ozone distribution over the subcontinent. Latitudinal variation of total column ozone from Nagarcoil to Anantanag has also been studied for the years 1979, 1994, 2005, and 2018, which indicates an increase in ozone concentration with latitude.
\end{abstract}

\section{Keywords}

Ozone, Indian Sub-Continent, Seasonal Variation, Satellite Data, Wind Profile 


\section{Introduction}

The increasing demands of the urban population and changing lifestyles are accelerating the development of industries and increasing the use of motor vehicles, thereby polluting the urban air. Therefore, in recent years, urbanization and Green House Gases (GHGs) emissions have adversely affected the air quality and caused an imbalance in the regional climate, and become a global issue [1] [2]. During 1971-2012, Greenhouse gas emissions in developing countries increased rapidly due to increased consumption of fossil fuels in the sectors of transportation, thermal power plants, industries, etc. [3]. An increase in GHG emissions in the atmosphere produces a warming effect on the environment and this causes climate change [4]. Carbon dioxide $\left(\mathrm{CO}_{2}\right)$, methane $\left(\mathrm{CH}_{4}\right)$, nitrous oxide $\left(\mathrm{NO}_{\mathrm{x}}=\mathrm{NO}+\mathrm{NO}_{2}\right)$, ozone $\left(\mathrm{O}_{3}\right)$, and volatile organic compounds (VOCs) are the important trace gases found in the atmosphere. These gases play a key role to enhance warming in the lower atmosphere and greatly influence the changes in air quality, climate change, and atmospheric chemistry [5].

The distribution and variability of atmospheric $\mathrm{O}_{3}$ are important as they influence global and regional climate systems in a serious manner. About $90 \%$ of total ozone in the atmosphere is found in the stratosphere, which absorb harmful solar ultraviolet radiation, and plays a major role in the photochemistry of the atmosphere [6] [7]. With the invention of the ozone layer depletion in the Antarctic region; research has intensified to study the variability of global total column ozone (TCO) distribution. Variability of TCO over the different parts of the globe has been examined in several studies using ground-based and satellite-borne instrumentation, and the results are quite promising in conjunction with the observed variability in solar UV radiation [8]-[13]. Ground and satellite-based measurements of TCO over many regions of the globe have shown a declining trend since the 1980s [14]-[25]. Many studies [26]-[32] have been undertaken to determine the variation of TCO over the Indian subcontinent, and they reported a substantial decreasing trend of TCO in the north Indian region.

Ozone in the lower atmosphere (tropospheric region) plays a crucial role in the chemistry of the troposphere and acts as a greenhouse gas due to its strong radiative forcing capacity [33]. Being a secondary air pollutant, $\mathrm{O}_{3}$ in the tropospheric region has been formed from its precursor gases $\left(\mathrm{CO}, \mathrm{NO}_{2}, \mathrm{VOC}\right.$ 's, $\mathrm{CH}_{4}$ ) in the presence of solar radiation through a series of photochemical reactions [34] [35]. The atmospheric dynamics in the form of vertical mixing from the stratosphere to the troposphere have also played a key role in the spatial distribution of tropospheric $\mathrm{O}_{3}$ concentration [36]. From the last decade, a reversal of the $\mathrm{O}_{3}$ trend in the atmosphere has been observed. The total column concentration keeps decreasing and tropospheric concentration continues to increasing [37] [38]. Observations and modeling investigations suggest that tropospheric $\mathrm{O}_{3}$ concentrations have been increasing in the lower troposphere over different parts of the globe [39]-[46]. In developing countries such as India and China, the concentrations of tropospheric ozone have been increasing due to enhanced 
emission of its precursor gases [47] [48], whereas in developed regions such as Europe, and the eastern US reduced anthropogenic emission of precursor gases led to decrease in ozone concentrations [49] [50] [51]. Studies of $\mathrm{NO}_{2}$ and $\mathrm{CO}_{2}$ by satellite observations indicate that the air quality in India is deteriorating, and will worse in the near future [52] [53] [54].

This manuscript deals with the statistical analysis of the variation of total and tropospheric ozone distribution over the Indian subcontinent by using satellite data. The decadal analysis shows a substantial declining trend of TCO over the north and northeast Indian region. Long term variation of TCO by linear regression analysis revealed that there is a marked decrease in TCO/year. Every year, on average, there was a decrease in TCO observed, which was maximum at Anantnag and minimum at Vishakapattanam. Also, the latitudinal variation of TCO shows an exponential increase from Nagarcoil to Anantnag. Further, the wind analysis shows that wind patterns play a crucial role in the change in the concentration of ozone in the Indian subcontinent.

\section{Selected Locations, Data Sources and Methodology}

\subsection{Selected Locations}

Twenty locations have been selected for the analysis of TCO and are listed in Table 1 .

Table 1. Selected location with latitude, longitude and elevation.

\begin{tabular}{|c|c|c|c|c|c|}
\hline No. & Location & Latitude & Longitude & Elevation (m) & Region \\
\hline 1 & Nagarcoil & 8.91 & 77.23 & 12 & \multirow{7}{*}{$\begin{array}{c}\text { South Indian } \\
\text { region }\end{array}$} \\
\hline 2 & Pondicherry & 11.54 & 79.51 & 3 & \\
\hline 3 & Kasargod & 12.18 & 75.51 & 18 & \\
\hline 4 & Panaji & 15.19 & 73.51 & 7 & \\
\hline 5 & Bellari & 15.91 & 76.54 & 485 & \\
\hline 6 & Vishakapattanam & 17.42 & 83.19 & 5 & \\
\hline 7 & Ramagundam & 18.46 & 79.26 & 179 & \\
\hline 8 & Ahmednagar & 19.58 & 74.47 & 649 & \multirow{6}{*}{$\begin{array}{l}\text { Middle Indian } \\
\text { region }\end{array}$} \\
\hline 9 & Raipur & 21.13 & 81.18 & 298 & \\
\hline 10 & Rajkot & 22.16 & 70.48 & 134 & \\
\hline 11 & Bhopal & 23.15 & 77.25 & 429 & \\
\hline 12 & Kharagpur & 22.20 & 87.19 & 29 & \\
\hline 13 & Patna & 25.32 & 85.10 & 53 & \\
\hline 14 & Aizawl & 23.43 & 92.44 & 1132 & \multirow{3}{*}{$\begin{array}{l}\text { Northeast } \\
\text { region }\end{array}$} \\
\hline 15 & Dibrugarh & 27.27 & 94.55 & 108 & \\
\hline 16 & Gangtok & 27.28 & 88.38 & 1437 & \\
\hline 17 & Lucknow & 26.52 & 80.56 & 128 & \multirow{4}{*}{$\begin{array}{l}\text { North Indian } \\
\text { region }\end{array}$} \\
\hline 18 & Jaipur & 26.54 & 75.46 & 431 & \\
\hline 19 & Chandigarh & 30.45 & 76.46 & 350 & \\
\hline 20 & Anantnag & 33.45 & 75.81 & 1601 & \\
\hline
\end{tabular}


For the comparison of total column variation, the selected locations are grouped into four categories, namely south Indian region, middle Indian region, northeast Indian region, and north Indian region. Nagarcoil, Pondicherry, Kasargod, Panaji, Bellari, Vishakapattanam, and Ramagundam are grouped under the South Indian region; Ahmednagar, Raipur Rajkot, Kharagpur, Bhopal, and Patna are grouped in the middle Indian region. Aizawl, Dibrugarh, Gangtok are clustered in the North East region, and the remaining locations Lucknow, Jaipur, Chandigarh, and Anantnag are treated as North Indian regions. Selected locations are shown in Figure 1.

\subsection{Satellite Data Used for the Study}

Total column ozone (TCO) overpass data were obtained from two different instruments: Total Ozone Mapping Spectrometer (TOMS) and Ozone Monitoring Instrument (OMI) on Earth Probe and AURA satellites respectively. TOMS measures backscattered UV solar radiances from the Earth's surface and from atop of clouds. OMI measures the complete spectrum from $270 \mathrm{~nm}$ to $500 \mathrm{~nm}$ at an average spectral resolution of $0.5 \mathrm{~nm}$. The sensor provides global daily coverage of columnar concentration of ozone, $\mathrm{NO}_{2}$, and formaldehyde. Online data is available from 2004 to the present. The spatial resolutions of the datasets are $1^{\circ}$ latitude $\times 1.25^{\circ}$ longitude for TOMS and $1^{\circ}$ latitude $\times 1^{\circ}$ longitude for OMI [55] [56]. The tropospheric column ozone data determined by subtracting measurements of microwave limb sounder (MLS) stratospheric column ozone from ozone monitoring instrument (OMI) measured total column ozone after adjusting the inter-calibration differences of the two instruments using the convective cloud differential (CCD) method used during the period 2005-2018 [57].

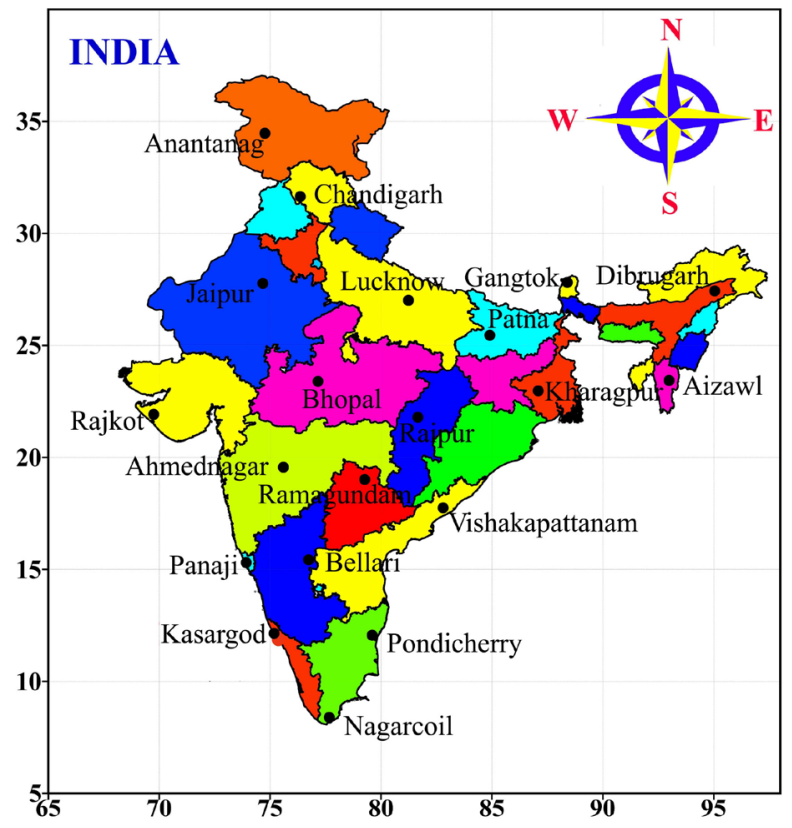

Figure 1. Location of site selected for the study. 


\subsection{Linear Regression Method for Long-Term Trend Analysis}

For computing the long term TCO variations, the monthly average total column $\mathrm{O}_{3}$ time series data were derived from the daily TOMS datasets A linear regression statistical model represented by $X=a * t+c$ is applied to monthly mean TCO data for each selected location. Here, " $X$ " denotes the monthly average TCO, " $a$ " denotes the coefficient of the slope in the linear regression line, " $t$ " represents the time period in months and " $c$ " represents the intercept. More details about the statistical model are available here [58] [59] [60]. The variation trend is obtained by using the equation,

$$
\text { Trend }=\frac{b \times 12 \times 10}{\operatorname{Avg}_{\mathrm{TCO}}} \times 100
$$

Here " $b$ " is the slope coefficient, $\operatorname{Avg}_{\text {TCO }}$ is the average value of TCO for the selected period.

\section{Results and Discussion}

\subsection{Temporal Variation of Total Column Ozone (TCO)}

Figure 2 shows the monthly average TCO over the study locations, and it shows a strong seasonal variation. All the locations show the maximum concentration in summer months and the minimum in winter months.

It has been found that in the south and middle Indian region, maximum monthly average TCO values ranging up to 290 DU during the months of April, May, and June. These high values in April-June were mostly linked to more sunlight hours, high temperatures, and low humidity. In the northeastern region, monthly averaged maximum TCO values were found in April and May, and in the northern Indian regions in February and March. Decreased TCO
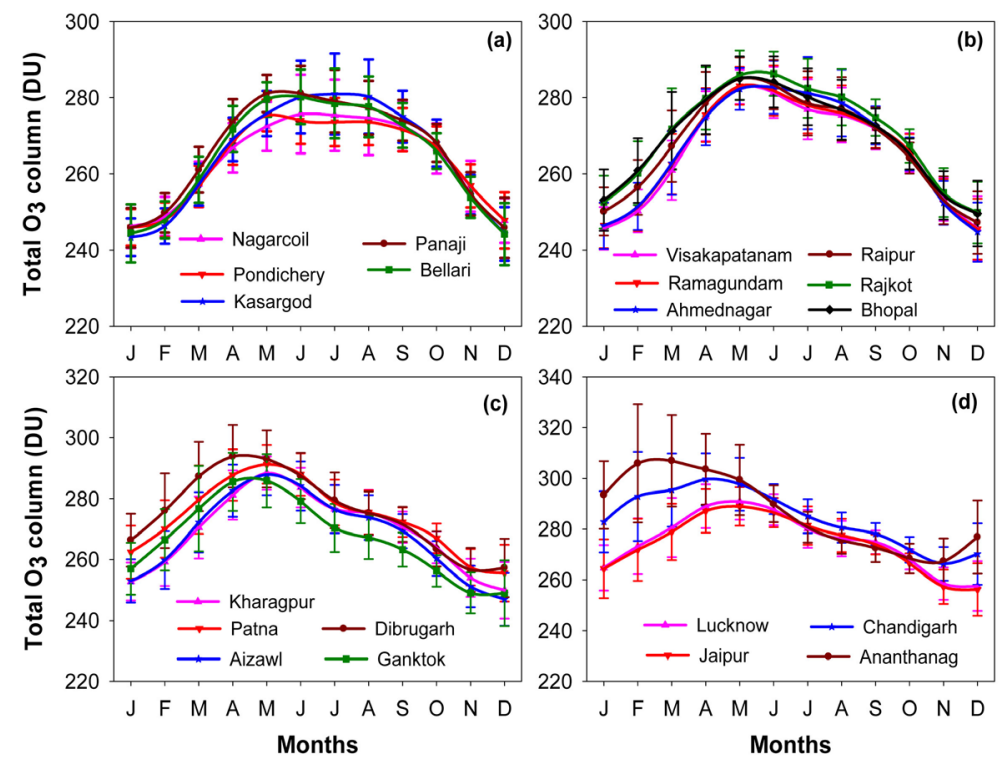

Figure 2. Monthly average variation of TCO in (a) South Indian, (b) Middle Indian, (c) Northeast Indian, (d) North Indian region from 1979 to 2018. 
concentrations were observed throughout the regions from June to November due to increased monsoon rainfall, cloud cover, large wind speed, and lower atmospheric temperatures. Further, the concentration of TCO in the whole area was found to be very low during the months of November-January, and a rising trend was observed from December to March.

Due to the favorable conditions, such as more sunlight hours, high temperatures, and low humidity, a high concentration of TCO has been observed in all the locations during the summer seasons. In the stratosphere, solar UV radiation plays an important role in the variation of $\mathrm{O}_{3}$ concentration. Brasseur, 1993 [61] reported that the changes in ultraviolet spectral irradiance can directly affect the formation of the stratospheric $\mathrm{O}_{3}$. A model study by Haigh, 1994 [62] revealed that a $1 \%$ increase in UV radiation at the maximum of a solar cycle will generate a $2 \%$ increase in $\mathrm{O}_{3}$ concentrations in the stratosphere. Atmospheric $\mathrm{O}_{3}$ is positively correlated with temperature and sunshine hours in a day, and it is negatively correlated with precipitation, humidity, wind speed, and cloud cover [63]. TCO decline was found to be statistically significant for all the months.

\subsection{Decadal Variation of Total Column Ozone}

The statistical analysis was carried out into two phases, from 1979 to 1994, and from 2005 to 2018, and the detail is shown in Table 2. It was found that

Table 2. Average TCO during (1979-1994) and (2005-2018), percentage of change, and variation trend/year by linear regression analysis.

\begin{tabular}{ccccc}
\hline \multirow{2}{*}{ Locations } & \multicolumn{2}{c}{ Average TCO (DU) during } & $\begin{array}{c}\text { Percentage } \\
\text { of change }\end{array}$ & $\begin{array}{c}\text { Variation } \\
\text { Trend/Year (\%) }\end{array}$ \\
\cline { 2 - 3 } Nagarcoil & $1979-1994$ & $2005-2018$ & -1.94 & -0.022 \\
Pondicherry & 265.37 & 260.21 & -1.88 & -0.019 \\
Kasargod & 264.75 & 259.77 & -1.98 & -0.027 \\
Panaji & 266.84 & 261.53 & -1.91 & -0.020 \\
Bellari & 267.56 & 262.44 & -2.18 & -0.022 \\
Vishakapattanam & 266.42 & 260.61 & -1.98 & -0.017 \\
Ramagundam & 266.75 & 261.45 & -1.68 & -0.018 \\
Ahmednagar & 267.22 & 262.71 & -1.93 & -0.020 \\
Raipur & 267.88 & 262.72 & -2.05 & -0.019 \\
Rajkot & 269.13 & 263.61 & -2.46 & -0.020 \\
Kharagpur & 271.98 & 265.28 & -2.04 & -0.021 \\
Bhopal & 270.28 & 264.78 & -2.57 & -0.019 \\
Patna & 271.7 & 264.71 & -2.41 & -0.022 \\
Aizawl & 270.44 & 264.58 & -2.68 & -0.029 \\
Dibrugarh & 278.26 & 263.2 & -4.09 & -0.034 \\
Gangtok & 276.56 & 265.87 & -3.88 & -0.033 \\
Lucknow & 276.9 & 267.19 & -3.50 & -0.025 \\
Jaipur & 276.02 & 269.22 & -2.46 & -0.025 \\
Chandigarh & 286.2 & 274.58 & -4.06 & -0.028 \\
Anantnag & 290.28 & 276.83 & -4.63 & -0.050 \\
\hline
\end{tabular}


Anantnag (-4.63\%), Dibrugarh (-4.09\%), and Chandigarh $(-4.06 \%)$ show a significant decreasing trend; whereas Gangtok (-3.88\%), Lucknow (-3.50\%) Aizawl (-2.68\%), and Jaipur (-2.46\%) shows a moderate decreasing trend.

A higher concentration of TCO was found at Anantnag (349 DU) whereas a lower concentration was found at Kasargod (227 DU). One important feature found in the study is that there is a marked decrease in TCO/year. Every year, on average, there was a decrease in TCO observed, which was maximum at Anantnag $(-0.050 \%)$ and minimum at Vishakapattanam $(-0.017 \%)$. Gangtok $(-0.033)$, Dibrugarh (-0.034), Aizawl (-0.029), and Chandigarh $(-0.028)$ are also experiencing a substantial decreasing trend/year. The variations in concentrations of TCO over selected locations for the periods (1979-1994 and 2005-2018) are shown in Figure 3. The decadal analysis shows a substantial declining trend of TCO over the north and northeast Indian region. The declining trend can be due to numerous factors. There is considerable aerosol loading in the northern and northeastern Indian regions, and these aerosols react with atmospheric gases and play an important role in reducing the tendency of TCO in these regions [64] [65].

\subsection{Long Term Variation of TCO}

Figure 4 shows the retrieved annual average variation of TCO over selected study areas. It is observed that the concentrations of TCO over the study locations are varying from $225 \mathrm{DU}$ to $350 \mathrm{DU}$, and TCO gradually increases from an average concentration near the equator to a maximum at high latitude. A linear
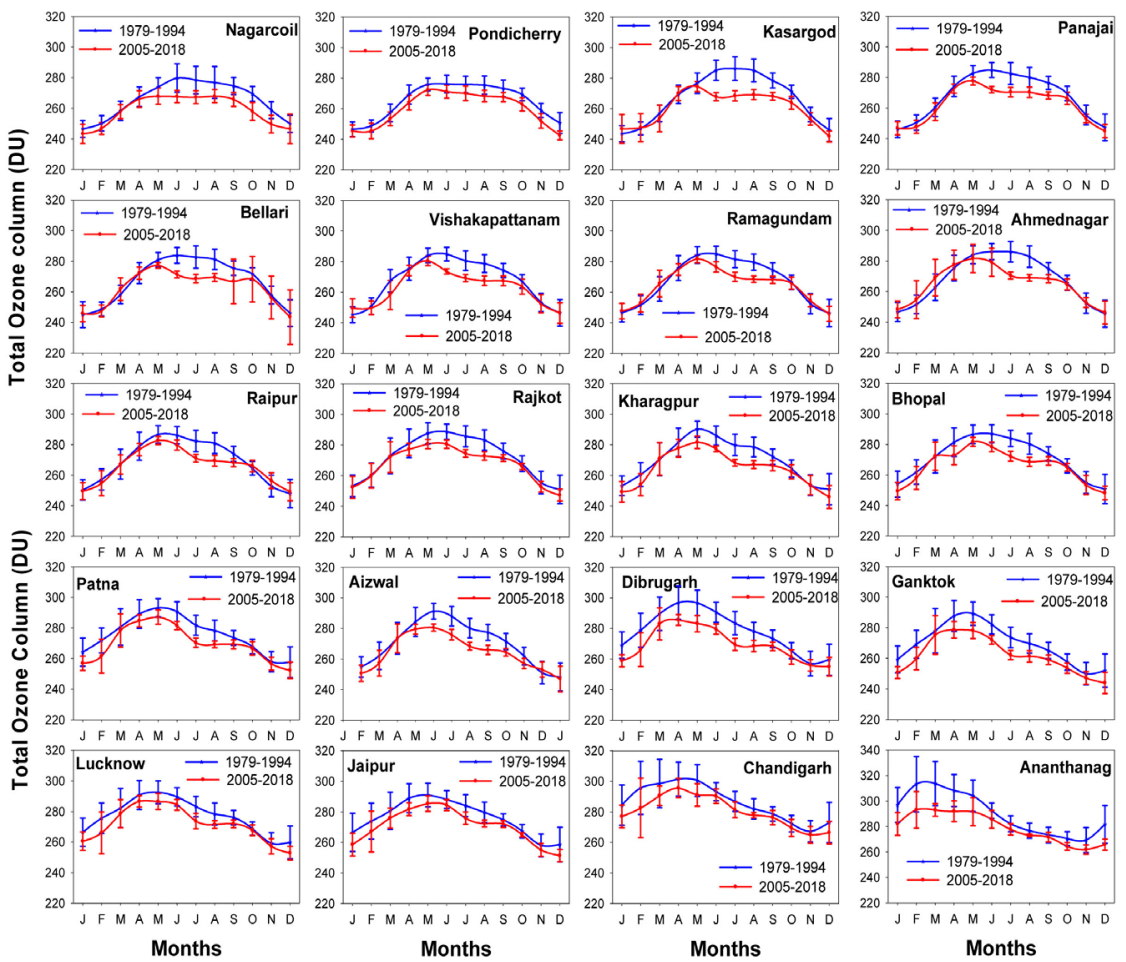

Figure 3. Variation of TCO for 1979-1994 and 2005-2011 for comparison. 

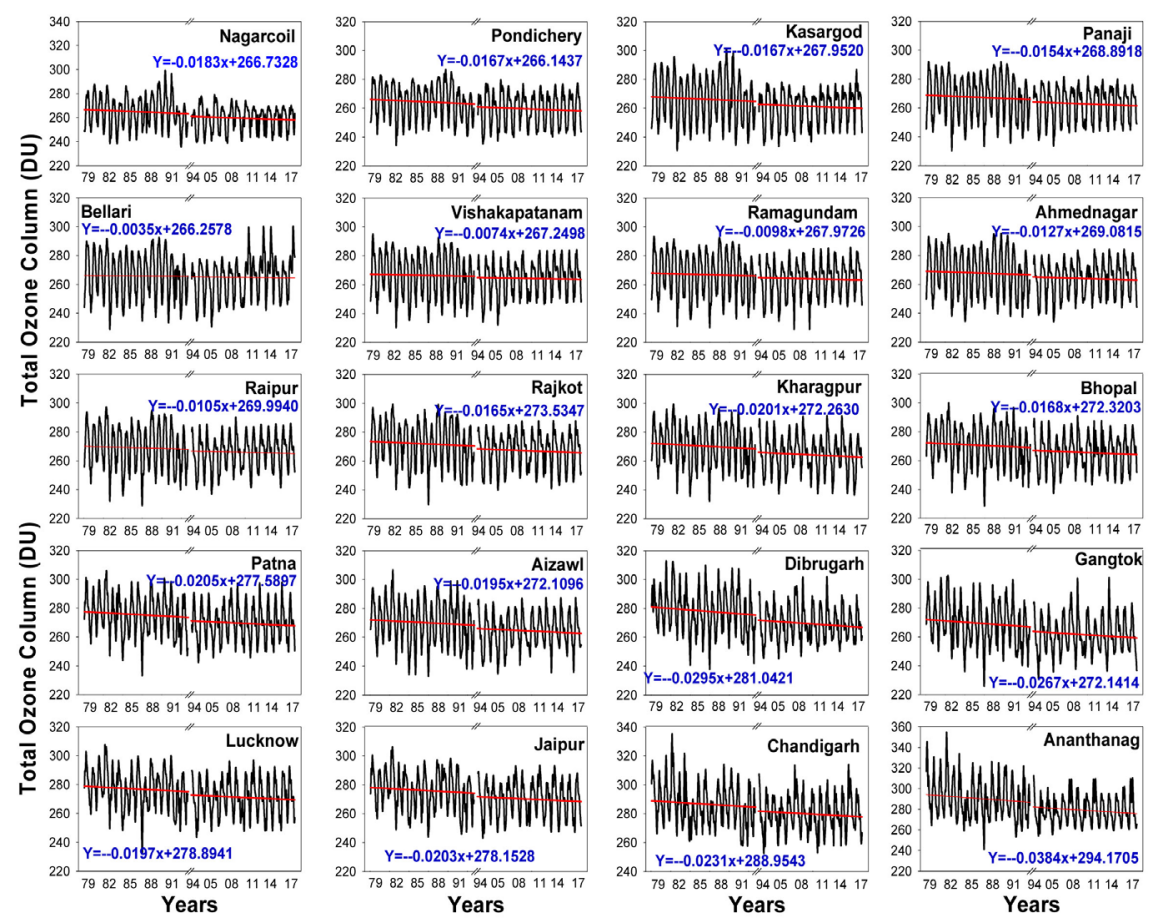

Figure 4. Annual average variation (1979-2018) of TCO with regression trend over selected locations.

regression trend has also been included in the figure, and the regression slope shows different for different sites.

A strong decline trend can be clearly seen in high latitude regions with TCO values ranging from 230DU to $348 \mathrm{DU}$. Further, the TCO concentrations in late 2018's were significantly lower than the corresponding levels recorded in 1979. The figure also shows the large inter annual variability of TCO concentrations over the study period. Factors such as the dynamical structure of the atmosphere, changes in air circulation from the troposphere to the stratosphere, changes in the anthropogenic $\mathrm{O}_{3}$ depletion substances, solar flux, variations in tropopause height, etc. were strongly controlled the annual variations of TCO [66] [67] [68].

\subsection{Latitudinal Variation of TCO}

In order to study the latitudinal variation of TCO, the average value of TCO was calculated from the monthly mean TCO for all the selected locations. Latitudinal variation of TCO for the years 1979, 1994, 2005, and 2018 is shown in Figure 5. From the figure, it is observed that latitudinal variation of TCO shows an exponential increase from Nagarcoil to Anantnag. In 2018, Anantnag $\left(33.45^{\circ} \mathrm{N}\right)$ recorded 32.52 DU more TCO than Nagarcoil $\left(8.9^{\circ} \mathrm{N}\right)$. There has been a substantial reduction of TCO (21.58 DU in Anantnag and 13.4 DU in Nagarcoil) observed from 1979 to 2018 from low to higher latitude regions. In addition to these, we found that the average TCO was increased by 2.52 DU per degree of latitude for the period of 1979-2018. 


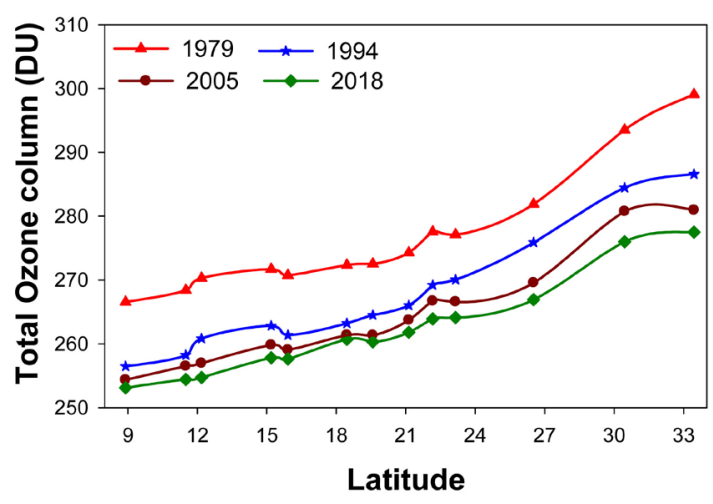

Figure 5. Latitudinal variation of total column ozone for different years.

A study by Bhattacharya and Bhoumick, 2012 [69] revealed that the TCO level has been increasing by $15 \mathrm{DU}$ as go from Trivandrum to New Delhi. Geographical and meteorological feature of the Indian sub-continent is one of the main reasons for the spatial variability of TCO concentration observed over different locations. The western and southern part of India is surrounded by the Arabian Sea and the Indian Ocean. The northwest region of India is generally dry. The northern region is bounded by Great Himalaya and Tibetan Plateau. The north-eastern part is categorized with dense vegetation, mountains, and Indo-Gangetic Plains. This may be the reason responsible for the observed temporal and spatial variation of TCO.

\subsection{Impact of Wind on Ozone Variation}

Monthly mean airflow patterns at 100 mbar over the Indian subcontinent for the year 2018 were retrieved from The National Center for Environmental Prediction (NCEP), reanalysis for studying the influence of wind pattern on the TCO over the Indian subcontinent is shown in Figure 6.

At $100 \mathrm{~m}$ bar level, the low latitude wind was much stronger than that at higher latitude. The TCO profile shows a distinct gradual variation from south to north direction over the subcontinent for all the seasons. During the first phase of the summer season (March, April), winds were stronger and the circulation was south westerly-westerly (from ocean to land). The south westerly-westerly wind gets weakened by May and the north-easterly wind starts in June. The wind direction remains northeasterly until October when the airflow was mostly from the continent. In March and April, the concentration of TCO shows a prominent change over all the study areas. It was noted that the concentration of TCO observed to be maximum in the northern region where the strong easterly wind profile existing. As monsoon approaches, the concentration of TCO was found to decrease throughout the north Indian region during which wind direction was from east-west. In the month of June, the relatively low easterly wind was observed in the south-middle Indian region, and the westerly wind was observed in the north Indian region. During July and August, the entire wind pattern in the sub-continent has changed into the east-west direction. 


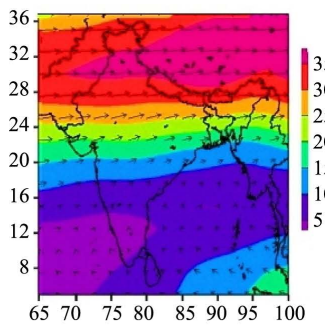

(a)

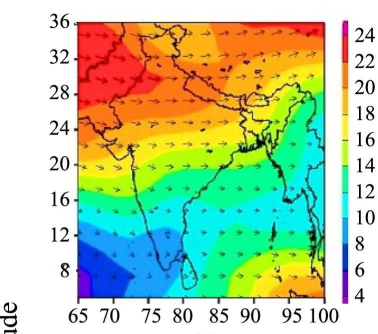

(d)

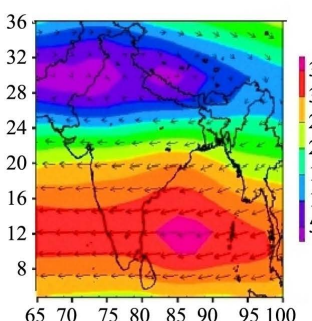

(g)

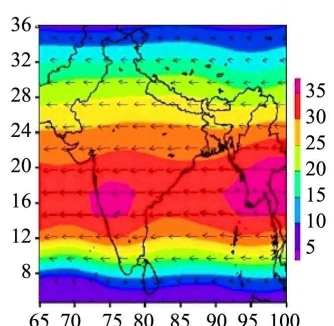

(j)

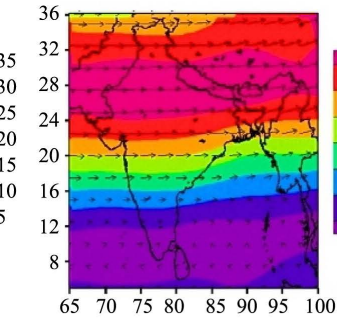

(b)

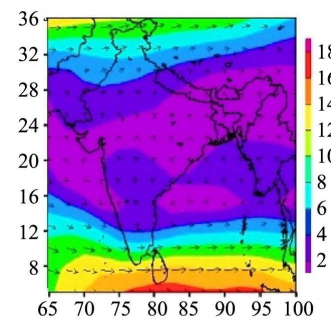

(e)

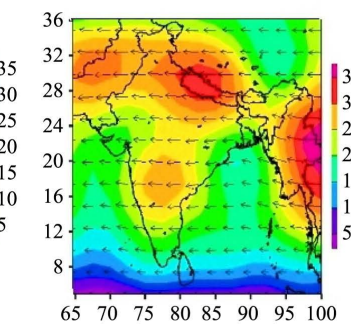

(h)

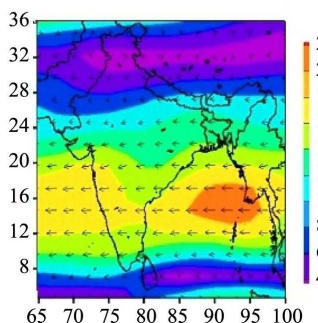

(k)

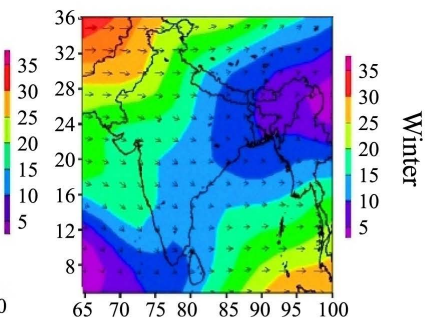

(c)

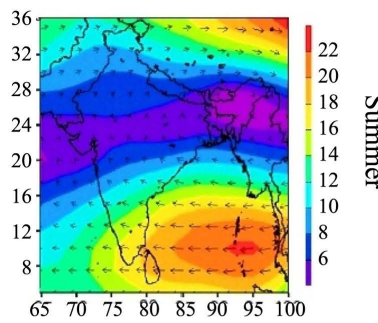

(f)

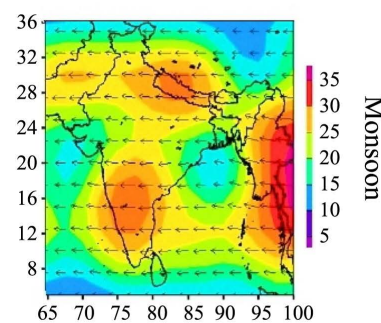

(i)

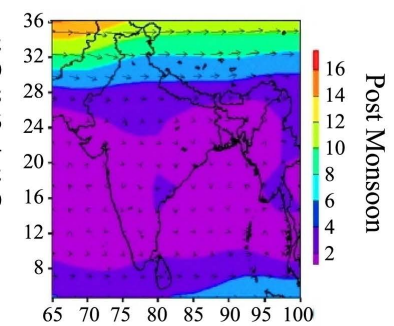

(1)

Longitude

Figure 6. Monthly mean air flow pattern at 100 mbar over the Indian subcontinent for the months (a) December, (b) January, (c) February, (d) March, (e) April, (f) May, (g) June, (h) July, (i) August, (j) September, (k) October, (l) November for the year 2018.

This profile can cause less concentration of TCO in the northern latitudes due to confinement of locally generated TCO [70].

\subsection{Variation of Tropospheric Ozone}

Figure 7 shows the monthly average concentrations of tropospheric $\mathrm{O}_{3}$ over selected locations of the Indian subcontinent by employing satellite data. From the figure, it is evident that tropospheric $\mathrm{O}_{3}$ shows significant monthly variations. The maximum concentration of tropospheric $\mathrm{O}_{3}$ was found in the summer months due to the enhanced photochemistry in the lower atmosphere. During June, July, and August, there was asubstantial reduction of tropospheric $\mathrm{O}_{3}$ 


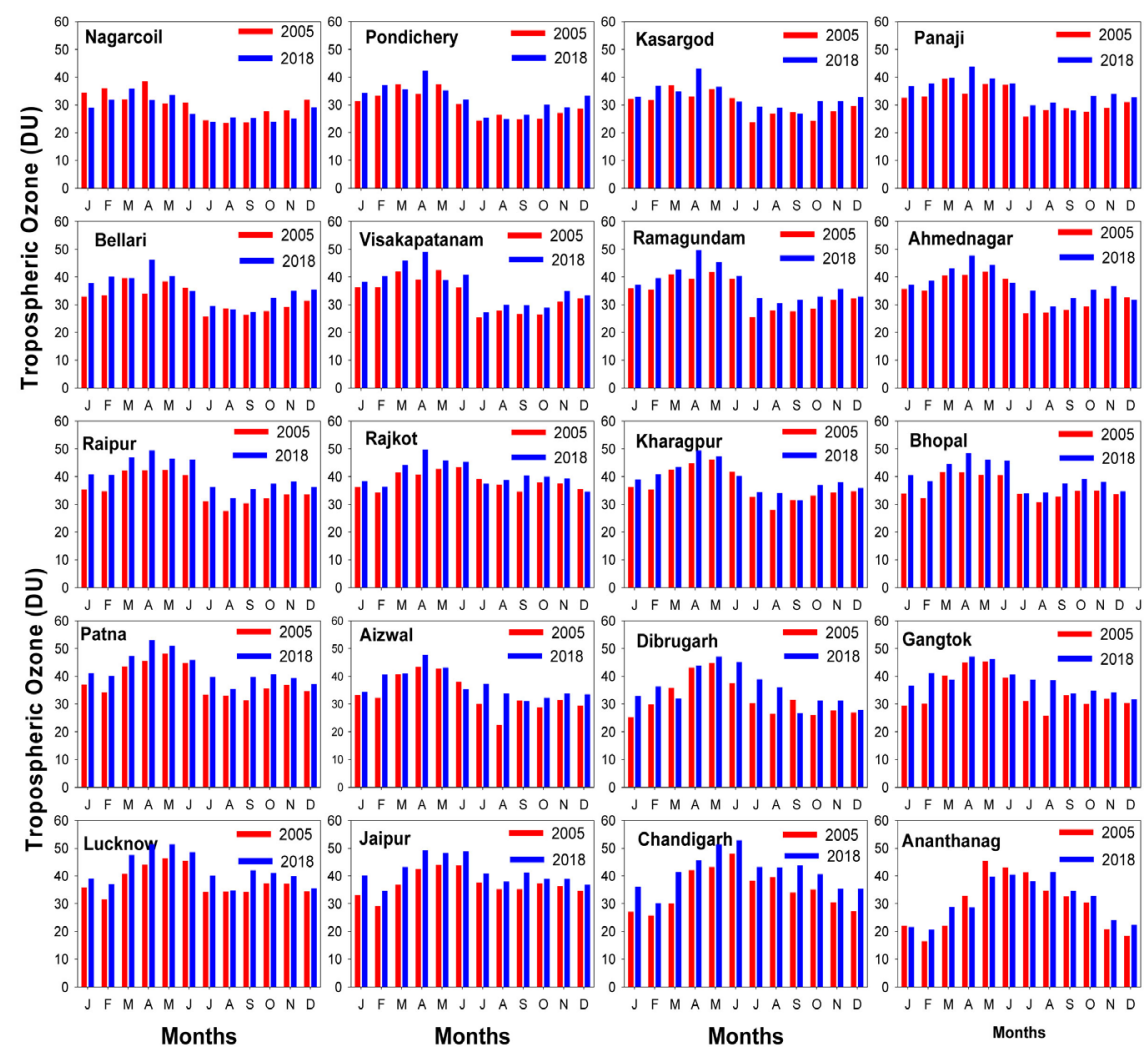

Figure 7. Monthly average tropospheric $\mathrm{O}_{3}$ over selected locations during 2005 and 2018.

observed due to the active south-west monsoon over these locations. In the winter months, the lower boundary layer height and the dry weather offer the elevation of concentration of tropospheric $\mathrm{O}_{3}$. A long-term satellite-based study conducted by Kalita and Bhuyan [71] on the Indian subcontinent observed the maximum concentrations of tropospheric $\mathrm{O}_{3}$ distribution in the northeastern (NE) and the Indo Gangetic Plains (IGP). A study on the variability of tropospheric $\mathrm{O}_{3}$ over the coastline of the Indian subcontinent by Kulkarni et al. [72], revealed that tropospheric $\mathrm{O}_{3}$ has a strong seasonal cycle over the Indian coastline, with a large variation over the upper east coast followed by the upper western coast. Table 3 shows the annual average variation of tropospheric $\mathrm{O}_{3}$ observed in 2005 and 2018 and the percentage of increase. From, the table it is clear that tropospheric $\mathrm{O}_{3}$ shows an increasing trend over all the locations with the maximum trend observed at Gangtok followed by Aizawl, Raipur, Anantnag, Vishakapattanam, and Ramagundam.

The long-term trends (2005-2018) in tropospheric $\mathrm{O}_{3}$ over the selected locations were carried out by linear regression analysis and are shown in Figure 8. From, the figure it is clear that the concentrations of tropospheric $\mathrm{O}_{3}$ show an increasing trend over all the locations. This increase in the trend of tropospheric $\mathrm{O}_{3}$ was mainly due to an increased anthropogenic emission of gases in and around the locations selected. Different studies show that the high concentration of $\mathrm{NO}_{2}$ in the atmosphere is the main reason for the increase in $\mathrm{O}_{3}$ concentration 


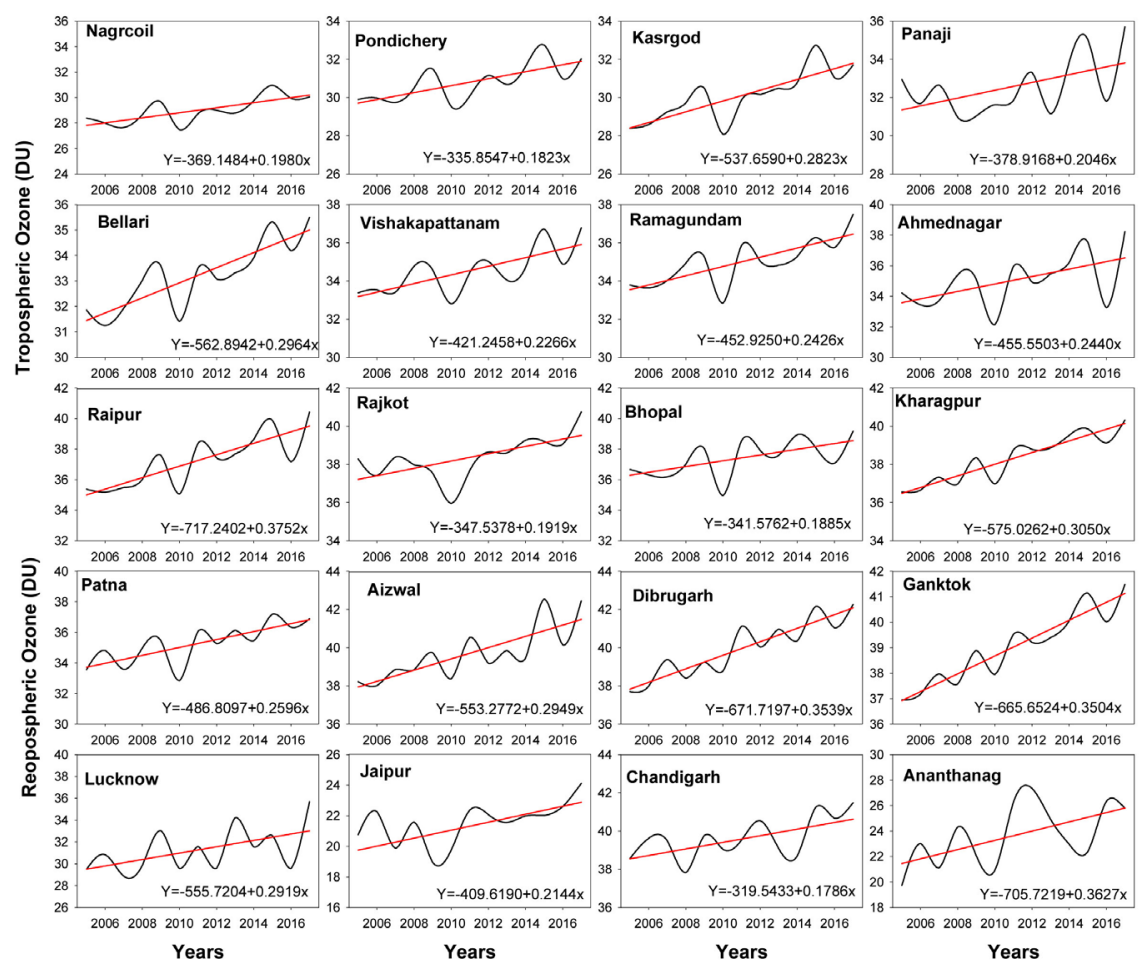

Figure 8. Annual average variation of tropospheric ozone over selected locations.

Table 3. Annual average tropospheric $\mathrm{O}_{3}$ and percentage of change over selected area.

\begin{tabular}{cccc}
\hline \multirow{2}{*}{ Locations } & Annual average tropospheric $\mathrm{O}_{3}(\mathrm{ppbv})$ & \multirow{2}{*}{ \% of change } \\
\cline { 2 - 3 } & 2005 & 2018 & 4.40 \\
Nagarcoil & 42.11 & 43.96 & 2.28 \\
Pondicherry & 43.86 & 44.86 & 4.23 \\
Kasargod & 43.68 & 45.53 & 3.80 \\
Panaji & 48.37 & 50.21 & 6.67 \\
Bellari & 48.52 & 51.76 & 7.85 \\
Vishakapattanam & 47.36 & 51.08 & 7.45 \\
Ramagundam & 50.60 & 54.37 & 2.67 \\
Ahmednagar & 54.06 & 56.73 & 9.96 \\
Raipur & 51.67 & 56.82 & 3.70 \\
Rajkot & 54.06 & 56.06 & 5.50 \\
Kharagpur & 50.26 & 55.76 & 6.27 \\
Bhopal & 53.70 & 57.78 & 6.22 \\
Patna & 54.13 & 57.50 & 9.97 \\
Aizawl & 50.43 & 55.46 & 6.75 \\
Dibrugarh & 50.98 & 54.42 & 17.27 \\
Gangtok & 59.86 & 70.20 & 7.01 \\
Lucknow & 54.56 & 58.38 & 7.35 \\
Jaipur & 55.25 & 59.31 & 2.16 \\
Chandigarh & 58.01 & 59.26 & 8.73 \\
Anantnag & 64.72 & 70.37 & \\
\hline
\end{tabular}


observed over different parts of the Indian region. Sheel et al. [73] point out that $\mathrm{NO}_{2}$ emissions in India have been increasing over the past few years due to rapid economic and industrial growth. The enhancement of $\mathrm{NO}_{2}$ over these regions is mainly due to the industries including power plants, vehicular exhaust, mining activities, etc. [74].

Figure 9(a) and Figure 9(b) show the monthly average annual variation of the spatial distribution of tropospheric $\mathrm{O}_{3}$ over the Indian sub-continent for the year 2005 and 2018. The enhanced $\mathrm{O}_{3}$ was found along the highly populated north and north-western part of India. It is also found that the tropospheric $\mathrm{O}_{3}$ concentration in all parts of the Indian subcontinent is much higher in 2018 than in 2005. The observed change in concentration of tropospheric $\mathrm{O}_{3}$ from 2005 to 2018 is shown in Figure 9(c). The elevated concentration of tropospheric $\mathrm{O}_{3}$ in 2018 was mainly due to the regional enhancement of precursors at low altitudes in the presence of sunlight. Nitrogen dioxide $\left(\mathrm{NO}_{2}\right)$ plays an important role in the production of tropospheric $\mathrm{O}_{3}$.

Studies based on bottom-up approaches indicate that the $\mathrm{NO}_{2}$ emissions have been increasing and will continue to increase over India in the coming years. The rate of change of tropospheric $\mathrm{O}_{3}$ simulated by regression analysis is plotted in Figure 9(d). The enhanced rate of change of $\mathrm{O}_{3}$ was observed in the IndioGangatic region and middle Indian regions. Biofuels used for cooking in rural areas, the presence of thermal power plants, steel, sugar, and other small industries
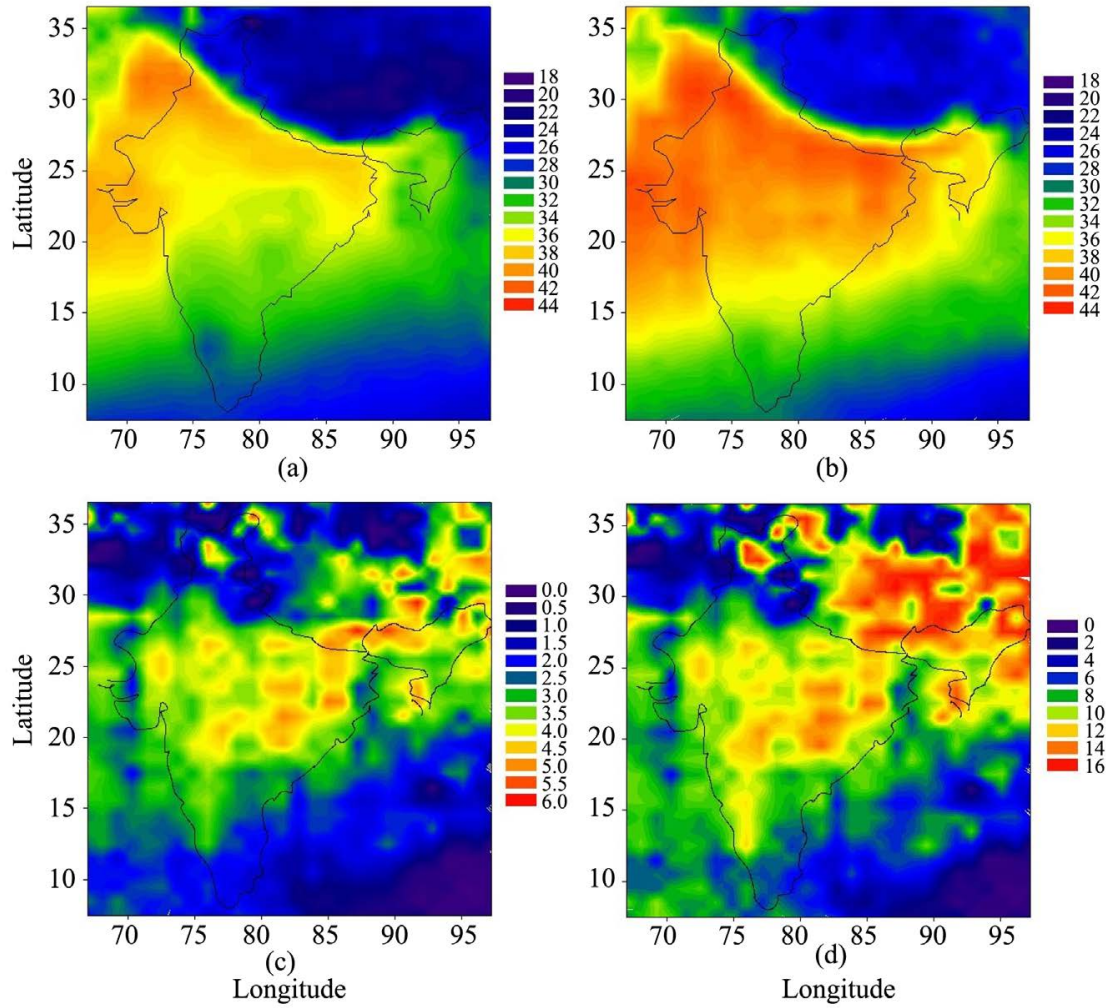

Figure 9. Annual average variation of tropospheric $\mathrm{O}_{3}$ in (a) 2005, (b) 2018, (c) changes observed from 2005 to 2018, (d) rate of change of ozone using regression analysis. 
leads to strong emissions of various pollutants in the sub-continent [75] [76]. "The decadal changes in tropospheric $\mathrm{O}_{3}$ have also been calculated over the Indian region during periods 2005 to 2018 and it was observed that during the period 2005 the average tropospheric $\mathrm{O}_{3}$ was $30.97 \mathrm{DU}$, whereas during 2018 it was a little higher at about $33.50 \mathrm{DU}$ with an increasing value of 2.53 . Though the difference is not too large, it indicates an increasing tendency. Hence, it can be said that the increasing concentration of GHGs during 2005-2018 was responsible for the higher level of the tropospheric $\mathrm{O}_{3}$ during this period over the region.

\section{Conclusion}

The distribution of total column, and tropospheric ozone in 20 locations in the Indian subcontinent was explored using the overpass data from on-board satellite instruments, TOMS and AURA/OMI. A decreasing trend in the total column ozone concentration, and an increasing trend in tropospheric ozone concentration were observed over selected locations. The monthly mean TCO shows a marked seasonal variation all over the locations, and was found to be varying from $227 \mathrm{DU}$ to $349 \mathrm{DU}$. The linear regression analysis revealed that TCO shows a declining trend in the northeastern and northern parts of India. A maximum decrease in TCO/year has been observed at Anantnag and a minimum at Vishakapattanam. An increasing trend of TCO has been observed due to latitudinal variation from Nagarcoil to Anantnag during the period 2005-2018. The geographical feature of the Indian subcontinent is one of the main reasons for the spatial variability of TCO concentration observed over different locations. The impact of wind on TCO has been analyzed by using NCEP reanalysis data. It was revealed that the TCO was observed to be maximum in the northern region where the strong easterly wind profile exists. As monsoon approaches, TCO was found to decrease throughout the north Indian region during which wind direction was from east to west. Analysis of the variation of tropospheric $\mathrm{O}_{3}$ revealed that a higher concentration of tropospheric $\mathrm{O}_{3}$ has been found in the summer season over all the selected locations due to the enhanced photochemistry, and minimum during the south-west monsoon. The rate of change of tropospheric $\mathrm{O}_{3}$ simulated by regression analysis shows an enhanced rate in the Indio-Gangetic region and middle Indian regions. The elevated concentration of tropospheric $\mathrm{O}_{3}$ observed in 2018 than 2005 was mainly due to the regional enhancement of precursors at low altitude and the transport of pollution by the wind. Detailed analysis of high-resolution satellite data, ground and sounding data and modeling studies are required for further validation.

\section{Acknowledgements}

The authors wish to express their sincere gratitude to NASA /NOAA, TOMS Ozone processing team for providing the total column $\mathrm{O}_{3}$ data, and Giovanni/mirador web portal for providing the data of Aura/OMI and MLS satellite over the Indian region. One of the authors, Resmi expresses her gratitude to 
Dr. R. Venkatachalam (Principal) and Dr. D. Manivannan (HOD of Physics) of Erode Arts and Science College Tamil Nadu for providing the necessary facilities.

\section{Conflicts of Interest}

The authors declare no conflicts of interest regarding the publication of this paper.

\section{References}

[1] Schwartz, S.E. (1996) The Whitehouse Effect: Shortwave Radiative Forcing of Climate by Anthropogenic Aerosols: An Overview. Journal of Aerosol Science, 27, 359-382. https://doi.org/10.1016/0021-8502(95)00533-1

[2] Ball, W.P., Dickerson, R.R., Doddridge, B.G., Stehr, J.W., Miller, T.L. and Savoie, D.L. (2003) Bulk and Size-Segregated Aerosol Composition Observed during INDOEX 1999: Overview of Meteorology and Continental Impacts. Journal of Geophysical Research, 108, 8001. https://doi.org/10.1029/2002JD002467

[3] Du, W.C. and Xi, X.H. (2018) How Does Urbanization Affect GHG Emissions? A Cross-Country Pane Threshold Data Analysis. Applied Energy, 229, 872-883. https://doi.org/10.1016/j.apenergy.2018.08.050

[4] Wang, W.C., Yung, Y.L., Lacis, A.A., Mo, T. and Hansen, J.E. (1976) Greenhouse Effects Due to Man-Made Perturbations of Trace Gases. Science, 194, 685-690. https://doi.org/10.1126/science.194.4266.685

[5] Nishanth, T., Praseed, K.M., Satheesh Kumar, M.K. and Valsaraj, K.T. (2014) Influence of Ozone Precursors and $\mathrm{PM}_{10}$ on the Variation of Surface $\mathrm{O}_{3}$ over Kannur, India. Atmospheric Research, 138, 112-124.

https://doi.org/10.1016/j.atmosres.2013.10.022

[6] Kowalok, M.E. (1993) Common Threads-Research Lessons from Acid Rain, Ozone Depletion, and Global Warming. Environment. Science and Policy for Sustainable Development, 35, 13-38. https://doi.org/10.1080/00139157.1993.9929107

[7] Feretis, E., Theodorakopoulos, P., Varotso, S.C., Etstathiou, M., Tzanis, C., Xirou, T., Alexandridou, N. and Aggelou, M. (2002) On the Plausible Association between Environmental Conditions and Human Eye Damage. Environmental Science and Pollution Research, 9, 163-165. https://doi.org/10.1007/BF02987482

[8] Varotsos, C. (1994) Solar Ultraviolet Radiation and Total Ozone, as Derived from Satellite and Ground-Based Instrumentation. Geophysical Research Letters, 21, 1787-1790. https://doi.org/10.1029/93GL02090

[9] Varotsos, C.A. (1998) Total Ozone Measurements over Athens: Inter Comparison between Dobson, TOMS (Version 6) and SBUV Measurements. International Journal of Remote Sensing, 19, 3327-3333. https://doi.org/10.1080/014311698214019

[10] Jaross, G., Taylor, S.L., Wellemeyer, C.G., Cebula, R.P., Huang, L.K., Stolarski, R.S. and McPeters, R.D. (2003) An Assessment of Long-Term Ozone Trend Uncertainties Using Total Ozone Mapping Spectrometers (TOMS). International Journal of Remote Sensing, 24, 329-338. https://doi.org/10.1080/01431160304971

[11] Vlamakis, A. (2005) Tropopause and Total Ozone at Mid-Latitudes. International Journal of Remote Sensing, 26, 3605-3612. https://doi.org/10.1080/01431160500076970

[12] Tzanis, C. (2009) Total Ozone Observations at Athens, Greece by Satellite-Borne 
and Ground-Based Instrumentation. International Journal of Remote Sensing, 30, 6023-6033. https://doi.org/10.1080/01431160902798411

[13] Oluleye, A. and Okogbue, E.C. (2013) Analysis of Temporal and Spatial Variability of Total Column Ozone over West Africa Using Daily TOMS Measurements. Atmospheric Pollution Research, 4, 387-397. https://doi.org/10.5094/APR.2013.044

[14] Stolarski, R.S., Bloomfield, P., McPeters, R.D. and Herman, J.R. (1991) Total Ozone Trends Deduced from Nimbus-7 TOMS Data. Geophysical Research Letters, 18, 1015-1018. https://doi.org/10.1029/91GL01302

[15] Stolarski, R.S., Bojkov, R., Bishop, L., Zerefos, C., Staehdin, J. and Zawodny, J. (1992) Measured Trends in Stratospheric Ozone. Science, 256, 342-349. https://doi.org/10.1126/science.256.5055.342

[16] Varotsos, C.A. and Cracknell, A.P. (1993) Ozone Depletion over Greece as Deduced from Nimbus-7 TOMS Measurements. International Journal of Remote Sensing, 14, 2053-2059. https://doi.org/10.1080/01431169308954021

[17] Cracknell, A.P. and Varotsos, C.A. (1994) Ozone Depletion over Scotland as Derived from Nimbus-7 TOMS Measurements. International Journal of Remote Sensing, 15, 2659-2668. https://doi.org/10.1080/01431169408954273

[18] Bojkov, R.D., Bishop, L. and Fioletov, V.E. (1995) Total Ozone Trends from Quality Controlled Ground-Based Data (1964-1994). Journal of Geophysical Research, 100, 25867-25876. https://doi.org/10.1029/95JD02907

[19] Chandra, S. and Varotsos, C.A. (1995) Recent Trends of the Total Column Ozone: Implications for the Mediterranean Region. International Journal of Remote Sensing, 16, 1765-1769. https://doi.org/10.1080/01431169508954516

[20] Chandra, S., Varotsos, C. and Flynn, L.E. (1996) The Mid-Latitude Total Ozone Trends in the Northern Hemisphere. Geophysical Research Letters, 23, 555-558. https://doi.org/10.1029/96GL00305

[21] Gernandt, H., Goersdorf, U., Claude, H. and Varotsos, C.A. (1995) Possible Impact of Polar Stratospheric Processes on Mid-Latitude Vertical Ozone Distributions. International Journal of Remote Sensing, 16, 1839-1850. https://doi.org/10.1080/01431169508954523

[22] McPeters, R.D., Hollandsworth, S.M., Flynn, L.E., Herman, J.R. and Seftor, C.J. (1996) Long-Term Ozone Trends Derived from the 16 Year Combined Nimbus 7/Meteor 3 TOMS Version 7 Record. Geophysical Research Letters, 23, 3699-3702. https://doi.org/10.1029/96GL03540

[23] Herman, J.R., Bhartia, P.K., Torres, O., Hsu, C., Seftor, C. and Celarier, E. (1997) Global Distribution of UV-Absorbing Aerosols from Nimbus 7/TOMS Data. Journal of Geophysical Research, 102, 16911-16922. https://doi.org/10.1029/96JD03680

[24] Harris, N.R.P., Ancellet, G., Bishop, L., Hofmann, D.J., Kerr, J.B., Mcpeters, R.D., Prendez, M., Randel, W.J., Staehelin, J., Subbaraya, B.H., Voltz-Thomas, A., Zawodny, J. and Zerefos, C.S. (1997) Trends in Stratospheric and Free Tropospheric Ozone. Journal of Geophysical Research, 102, 1571-1590. https://doi.org/10.1029/96JD02440

[25] Sahoo, A., Sarkar S., Singh, R.P., Kafatos, M. and Summers, M.E. (2005) Declining trend of TCO over the Northern Parts of India. International Journal of Remote Sensing, 26, 3433-3440. https://doi.org/10.1080/01431160500076467

[26] Singh, R.P., Sarkar, S. and Singh, A. (2002) Effect of El Niño on Inter-Annual Variability of Ozone during the Period 1978-2000 over the Indian Sub-Continent and China. International Journal of Remote Sensing, 23, 2449-2456. https://doi.org/10.1080/01431160110075893 
[27] Ganguly, D.N. and Iyer, K.N. (2005) Study of Variations in Columnar Ozone Concentration at Rajkot. Journal of Indian Geophysical Union, 9, 189-196.

[28] Kalapureddy, M.C.R., Ernest Raj, P. and Devara, P.C.S. (2008) Total Column Ozone Variations over Oceanic Region around Indian Sub-Continent during Pre-Monsoon of 2006. Atmospheric Chemistry and Physics, 8, 3143-3162.

https://doi.org/10.5194/acpd-8-3143-2008

[29] Patil, S.D. and Revadekar, J.V. (2009) Extremes in Total Ozone Content over Northern India. International Journal of Remote Sensing, 30, 2389-2397. https://doi.org/10.1080/01431160802549427

[30] Kalita, G., Bhuyan, P.K. and Bhuyan, K. (2010) Variation of Total Columnar Ozone Characteristics over Dibrugarh, India and Comparison with Satellite Observations over the Indian Subcontinent. Indian Journal of Physics, 84, 635-639. https://doi.org/10.1007/s12648-010-0063-6

[31] Pal, C. (2010) Variability of Total Ozone over India and Its Adjoining Regions during 1997-2008. Atmospheric Environment, 44, 1927-1936. https://doi.org/10.1016/j.atmosenv.2010.01.028

[32] Meena, G.S. and Patil, S.D. (2011) Variation of Total Column Ozone along the Monsoon trough Region over North India. International Journal of Remote Sensing, 32, 2581-2590. https://doi.org/10.1080/01431161003698435

[33] Kondratyev, K.Y. and Varotsos, C.A. (2001) Global Tropospheric Ozone Dynamics. Environmental Science and Pollution Research, 8, 57-62. https://doi.org/10.1007/BF02987295

[34] Khalil, M.A.K. and Rasmussen, R.A. (1988) Carbon Monoxide in the Earth's Atmosphere-Indications of a Global Increase. Nature, 332, 242-245.

https://doi.org/10.1038/332242a0

[35] Dianov, K.V.I. and Atkinson, R. (1989) Stratospheric Measurements of Atmospheric Carbon Monoxide and Methane, Seasonal Variation and Long Term Trends. Journal of Atmospheric Chemistry, 8, 153-164. https://doi.org/10.1007/BF00053720

[36] Efstathiou, M.N., Varotsos, C.A., Singh, R.P., Cracknell, A.P. and Tzanis, C. (2003) On the Longitude Dependence of Total Ozone Trends over Middle-Latitudes. International Journal of Remote Sensing, 24, 1361-1367.

https://doi.org/10.1080/0143116021000044814

[37] Kondratyev, K.Y., Varotsos, C.A. and Cracknell, A.P. (1994) Total Ozone Amount Trend at St-Petersburg as Deduced from NIMBUS-7 TOMS Observations. International Journal of Remote Sensing, 15, 2669-2677. https://doi.org/10.1080/01431169408954274

[38] Varotsos, C.A., Kondratyev, K.Y. and Cracknell, A.P. (2000) New Evidence for Ozone Depletion over Athens, Greece. International Journal of Remote Sensing, 21, 2951-2955. https://doi.org/10.1080/01431160050121366

[39] Oltmans, S.J., Lefohn, A.S., Scheel, H.E., Harris, J.M., Levy II, H., Galbally, I.E., Brunke, E.-G., Meyer, C.P., Lathrop, J.A., Johnson, B.J., Shadwick, D.S., Cuevas, E., Schmidlin, F.J., Tarasick, D.W., Claude, H., Kerr, J.B., Uchino, O. and Mohnen, V. (1998) Trends of Ozone in the Troposphere. Geophysical Research Letters, 25, 139-142. https://doi.org/10.1029/97GL03505

[40] Lee, S.H., Akimoto, H., Nakane, H., Kurnosenko, S. and Kinjo, Y. (1998) Increase of Tropospheric Ozone at Okinawa, Japan. Geophysical Research Letters, 25, 1637-1640. https://doi.org/10.1029/98GL01224

[41] Parrish, D.D., Law, K.S., Staehelin, J., Derwent, R., Cooper, O.R., Tanimoto, H., 
Volz-Thomas, H., Gilge, S., Scheel, H.-E., Steinbacher, M. and Chan, E. (2013) Lower Tropospheric Ozone at Northern Mid-Latitudes: Changing Seasonal Cycle. Geophysical Research Letters, 40, 1631-1636. https://doi.org/10.1002/grl.50303

[42] Cooper, O.R., Parrish, D.D., Ziemke, J.R., Balashov, N.V., Cupeiro, M., Galbally, I., Gilge, S., Horowitz, L., Jensen, N.R., Lamarque, J.-F., Naik, V., Oltmans, S.J., Schwab, J., Shindell, D.T., Thompson, A.M., Thouret, V., Wang, Y. and Zbinden, R.M. (2014) Global Distribution and Trends of Tropospheric Ozone: An Observation-Based Review. Elementa: Science of the Anthropocene, 2, 29.

https://doi.org/10.12952/journal.elementa.000029

[43] Lee, H.J., Kim, S.W., Brioude, J., Cooper, O.R., Frost, G.J., Kim, C.H., Park, R.J., Trainer, M. and Woo, J.H. (2014) Transport of $\mathrm{NO}_{\mathrm{x}}$ in East Asia Identified by Satellite and In-Situ Measurements and Lagrangian Particle Dispersion Model Simulations. Journal of Geophysical Research, 119, 2574-2596.

https://doi.org/10.1002/2013JD021185

[44] Zhang, Y., Cooper, O.R., Gaudel, A., Thompson, A.M., Nedelec, P., Ogino, S.Y. and West, J.J. (2016) Tropospheric Ozone Change from 1980 to 2010 Dominated by Equatorward Re-Distribution of Emissions. Nature Geoscience, 9, 875-879. https://doi.org/10.1038/ngeo2827

[45] Saraf, N. and Beig, G. (2004) Long-Term Trends in Tropospheric Ozone over the Indian Tropical Region. Geophysical Research Letters, 31, L05101. https://doi.org/10.1029/2003GL018516

[46] Ziemke, J.R., Oman, L.D., Strode, S.A., Douglass, A.R., Olsen, M.A., McPeters, R.D., Bhartia, P.K., Froidevaux, L., Labow, G.J., Witte, J.C., Thompson, A.M., Haffner, D.P., Kramarova, N.A., Frith, S.M., Huang, L.K., Jaross, G.R., Seftor, C.J., Deland, M.T. and Taylor, S.L. (2019) Trends in Global Tropospheric Ozone Inferred from a Composite Record of TOMS/OMI/MLS/OMPS Satellite Measurements and the MERRA-2 GMI Simulation. Atmospheric Chemistry and Physics, 19, 3257-3269. https://doi.org/10.5194/acp-19-3257-2019

[47] Sun, L., Xue, L., Wang, T., Gao, J., Ding, A., Cooper, O.R., Lin, M., Xu, P., Wang, Z., Wang, X., Wen, L., Zhu, Y., Chen, T., Yang, L., Wang, Y., Chen, J. and Wang, W. (2016) Significant Increase of Summertime Ozone at Mount Tai in Central Eastern China. Atmospheric. Chemistry and Physics, 16, 10637-10650.

https://doi.org/10.5194/acp-16-10637-2016

[48] Wang, T., Xue, L., Brimblecombe, P., Lam, Y.F., Li, L. and Zhang, L. (2017) Ozone Pollution in China: A Review of Concentrations, Meteorological Influences, Chemical Precursors, and Effects. Science of the Total Environment, 575, 1582-1596.

https://doi.org/10.1016/j.scitotenv.2016.10.081

[49] Oltmans, S.J., Lefohn, A.S., Shadwick, D., Harris, J.M., Scheel, H.E., Galbally, I., Tarasick, D.W., Johnson, B.J., Brunke, E.G., Claude, H., Zeng, G., Nichol, S., Schmidlin, F., Davies, J., Cuevas, E., Redondas, A., Naoe, H., Nakano, T. and Kawasato, T. (2013) Recent Tropospheric Ozone Changes-A Pattern Dominated by Slow or No Growth. Atmospheric Environment, 67, 331-351. https://doi.org/10.1016/j.atmosenv.2012.10.057

[50] Strode, S.A., Rodriguez, J.M., Logan, J.A., Cooper, O.R., Witte, J.C., Lamsal, L.N., Damon, M., Van Aartsen, B., Steenrod, S.D. and Strahan, S.E. (2015) Trends and Variability in Surface Ozone over the United States. Journal of Geophysical Research: Atmospheres, 120, 9020-9042. https://doi.org/10.1002/2014JD022784

[51] Lin, M., Horowitz, L.W., Payton, R., Fiore, A.M. and Tonnesen, G. (2017) US Surface Ozone Trends and Extremes from 1980 to 2014: Quantifying the Roles of Rising Asian Emissions, Domestic Controls, Wildfires, and Climate. Atmospheric 
Chemistry and Physics, 17, 2943-2970. https://doi.org/10.5194/acp-17-2943-2017

[52] Geddes, J.A., Martin, R.V., Boys, B.L. and van Donkelaar, A. (2016) Long-Term Trends Worldwide in Ambient $\mathrm{NO}_{2}$ Concentrations Inferred from Satellite Observations, Environmental Health Perspectives, 124, 281-289.

https://doi.org/10.1289/ehp.1409567

[53] Ghude, S.D., Chate, D.M., Jena, C., Beig, G., Kumar, R., Barth, M.C., Pfister, G.G., Fadnavis, S. and Pithani, P. (2016) Premature Mortality in India Due to $\mathrm{PM}_{2.5}$ and Ozone Exposure. Geophysical Research Letters, 43, 4650-4658.

https://doi.org/10.1002/2016GL068949

[54] Krotkov, N.A., McLinden, C.A., Li, C., Lamsal, L.N., Celarier, E.A., Marchenko, S.V., Swartz, W.H., Bucsela, E.J., Joiner, J., Duncan, B.N., Boersma, K.F., Veefkind, J.P., Levelt, P.F., Fioletov, V.E., Dickerson, R.R., He, H., Lu, Z. and Streets, D.G. (2016) Aura OMI Observations of Regional $\mathrm{SO}_{2}$ and $\mathrm{NO}_{2}$ Pollution Changes from 2005 to 2015. Atmospheric Chemistry and Physics, 16, 4605-4629.

https://doi.org/10.5194/acp-16-4605-2016

[55] McPeters, R.D., Bhartia, P.K., Krueger, A.J., Herman, J.R., Wellemeyer, C.G., Seftor, C.J., Jaross, G., Torres, O., Moy, L., Labow, G., Byerly, W., Taylor, S.L., Swissler, T. and Cebula, R.P. (1998) Earth Probe Total Ozone Mapping Spectrometer (TOMS): Data Products User's Guide. NASA Technical Publication, 206895.

[56] Aculinin, A. (2006) Variability of Total Column Ozone Content Measured at Chisinau Site, Republic of Moldova. Moldavian Journal of Physical Science, 5, 240-248.

[57] Ziemke, J.R., Chandra, S. and Duncan, B.N. (2006) Tropospheric Ozone Determined from Aura OMI and MLS: Evaluation of Measurements and Comparison with the Global Modeling Initiative's Chemical Transport Model. Journal of Geophysical Research, 111, D19303. https://doi.org/10.1029/2006JD007089

[58] Jain, S.L., Kulkarni, P.S., Ghude, S.D., Polade, S.D., Arya, B.C. and Dubey, P.K. (2008) Trend Analysis of Total Column Ozone over New Delhi, India. MAPAN. Journal Metrology Society of India, 23, 63-69.

[59] Toihir, A.M., Portafaix, T., Sivakumar, V., Bencherif, H., Pazmino, A. and Begue, N. (2018) Variability and Trend in Ozone over the Southern Tropics and Subtropics. Annales Geophysicae, 36, 381-404. https://doi.org/10.5194/angeo-36-381-2018

[60] Potdar, S.S., Nade, D.P., Pawar, R.P., Victor, N.J., Nikte, S.S., Chavan, G.A., Taori, A. and Singh, D. (2018) Statistical Analysis of Total Column Ozone during Three Recent Solar Cycles over India. Journal of Atmospheric and Solar-Terrestrial Physics, 181, 44-54. https://doi.org/10.1016/j.jastp.2018.10.015

[61] Brasseur, G. (1993) The Response of the Middle Atmosphere to Long Term and Short-Term Solar Variability: A Two-Dimensional Model. Journal of Geophysical Research, 98, 23079-23090. https://doi.org/10.1029/93JD02406

[62] Haigh, J.D. (1994) The Role of Stratospheric Ozone in Modulating the Solar Radiative Forcing of Climate. Nature, 370, 544-546. https://doi.org/10.1038/370544a0

[63] Resmi, C.T., Nishanth, T., Satheesh Kumar, M.K., Balachandramohan, M. and Valsaraj, K.T. (2020) Long Term Variation of Air Quality Influenced by Surface Ozone in a Coastal Site in India: Association with Synoptic Meteorological Conditions with Model Simulations. Atmosphere, 11, 193. https://doi.org/10.3390/atmos11020193

[64] Sharma, M., Kiran, Y.N.V.M. and Shandilya, K.K. (2003) Investigations into Formation of Atmospheric Sulfate under High $\mathrm{PM}_{10}$ Concentrations. Atmospheric Environment, 37, 2005-2013. https://doi.org/10.1016/S1352-2310(03)00005-0

[65] Bonasoni, P., Calzolari, F., Cristofanelli, P., Bonafe, U., Evangelisti, F., van Dingenen, R. and Balkanski, Y. (2001) Ozone and Aerosol Correlation during Sahara Dust 
Transport Episodes at Mount Climone during Minatroc Project. 8th European Symposium on the Physico-Chemical Behavior of Atmospheric Pollutants, NASA Astrophysics Data Report, Torino.

[66] Soukharev, B. (1999) On the Solar/QBO Effect on the Interannual Variability of Total Ozone and the Stratospheric Circulation over Northern Europe. Journal of Atmospheric and Solar-Terrestrial Physics, 61, 1093-11091. https://doi.org/10.1016/S1364-6826(99)00079-6

[67] Appenzeller, C., Weiss, A.K. and Staehelin, J. (2000) North Atlantic Oscillation Modulates Total Ozone Winter Trends. Geophysical Research Letters, 27, 1131-1134. https://doi.org/10.1029/1999GL010854

[68] Staehelin, J., Harris, N.R.P., Appenzeller, C., Eberhard, J. and Piechowski, M. (2001) Observations of Ozone Trends. Reviews of Geophysics, 39, 231-290.

https://doi.org/10.1029/1999RG000059

[69] Bhattacharya, R. and Bhoumick, A. (2012) Trend Analysis of Total Column Ozone over India Using TOMS Data from 1979 to 2010. International Journal of Engineering Science and Technology, 4, 2159-2166.

[70] Kalita, G., Pathak, B., Bhuyan, P.K. and Bhuyan, K. (2011) Impact of Zonal Wind on Latitudinal Variation of Total Columnar Ozone over the Indian Peninsula. International Journal of Remote Sensing, 32, 9509-9520. https://doi.org/10.1080/01431161.2011.564221

[71] Kalita, G. and Bhuyan, P.K. (2011) Spatial Heterogeneity in Tropospheric Column Ozone over the Indian Subcontinent: Long-Term Climatology and Possible Association with Natural and Anthropogenic Activities. Advances in Meteorology, 2011, Article ID: 924516. https://doi.org/10.1155/2011/924516

[72] Kulkarni, P.S., Ghude, D.S., Jain, S.L., Arya, B.C. and Dubey, P.K. (2011) Tropospheric Ozone Variability over the Indian Coastline and Adjacent Land and Sea. International Journal of Remote Sensing, 32, 1545-1559. https://doi.org/10.1080/01431160903571825

[73] Sheel, V., Lal, S., Richter, A. and Burrows, J.P. (2010) Comparison of Satellite Observed Tropospheric $\mathrm{NO}_{2}$ over India with Model Simulations. Atmospheric Environment, 44, 3314-3321. https://doi.org/10.1016/j.atmosenv.2010.05.043

[74] Sahu, S.K., Beig, G. and Parkhi, N.S. (2012) Emerging Pattern of Anthropogenic $\mathrm{NO}_{\mathrm{x}}$ Emission over Indian Subcontinent during 1990s and 2000s. Atmospheric Pollution Research, 3, 262-269. https://doi.org/10.5094/APR.2012.021

[75] Ghude, S.D., Fadnavis, S., Beig, G., Polade, S.D. and van der, A.R.J. (2008) Detection of Surface Emission Hot Spots, Trends, and Seasonal Cycle from Satellite-Retrieved $\mathrm{NO}_{2}$ over India. Journal of Geophysical Research, 113, D20305. https://doi.org/10.1029/2007JD009615

[76] Kar, J., Jones, D.B.A., Drummond, J.R., Attié, J.L., Liu, J., Zou, J., Nichitiu, F., Seymour, M.D., Edwards, D.P., Deeter, M.N., Gille, J.C. and Richter, A. (2008) Measurement of Low-Altitude CO over the Indian Subcontinent by MOPITT. Journal of Geophysical Research, 113, D16307. https://doi.org/10.1029/2007JD009362 